\title{
Silicate Sorption on Ankerite from a Standard Silicate Solution
}

\author{
Katalin Kopecskó1, Ali Al Dabbas* \\ 1 Department of Engineering Geology and Geotechnics, Faculty of Civil Engineering, Budapest University of Technology and \\ Economics, H-1111 Budapest, 3 Műegyetem rakpart, Hungary \\ * Corresponding author, e-mail: ali.al.dabbas@emk.bme.hu
}

Received: 03 August 2020, Accepted: 27 October 2020, Published online: 04 May 2021

\begin{abstract}
The effect of geological deposition conditions on the durability of glass used for radioactive waste disposal is investigated in this study. Iron mineral compositions or other near-field parameters within the final disposal repository may influence the durability of highly radioactive glass. The experimental study of silicate sorption by natural Ankerite is presented in this article. A preliminary analysis was conducted to determine the difference in silicon concentrations in standard solution in the presence of natural Ankerite utilizing the graphite furnace atomic absorption method. All of the standard solutions were diluted from a saturated silicate stock solution. Natural Ankerite mineral samples collected in Rudabánya, Hungary, demonstrated heavy $\left(\mathrm{H}_{4} \mathrm{SiO}_{4}\right)$ sorption at their interface.

Batch experiments with specific masses of natural Ankerite and silicate solution were conducted to demonstrate a better understanding of silicate reduction in solution due to Ankerite's sorption mechanism, demonstrating that Ankerite has the capacity to uptake silicate. The desorption of adsorbed silicate was investigated, and it was discovered that only very minimal quantities of silicate were returned to the solution, resulting in tiny reversed concentrations of silicate, perhaps indicating chemisorption.

The experiment reported the highest averaged adsorption of silicate and the lowest averaged desorption capacities of $98.9 \%$ and 3.7 percent respectively at a higher Ankerite Surface Area to Volume of solution, $(\mathrm{SA} / \mathrm{V})=3600 \mathrm{~m}^{-1}$, however the lowest averaged adsorption and the highest averaged desorption capacities of $85.8 \%$ and $8.9 \%$ respectively at a lower SA/V $=480 \mathrm{~m}^{-1}$.
\end{abstract}

\section{Keywords}

ankerite, silicate solution, silicate sorption

\section{Introduction}

Nuclear power plants are the largest in number among all nuclear facilities and produce the greatest volume of radioactive wastes. The nature and amounts of wastes produced in a nuclear power plant depend on the type of reactor, its specific design features, operating conditions and on the fuel integrity. These radioactive wastes contain activated radionuclides from structural, moderator and coolant materials i.e. corrosion products and fission product contamination arising from the fuel [1]. Several methods applied for the treatment and conditioning of waste generated at nuclear power plants have reached a high degree of affectivity and reliability and are being further developed to improve the safety and economy of the whole waste management system.

Long-lived radioactive wastes are mainly generated in-vessel component replacement [2] or neutron irradiated beryllium which require permanent disposal in geological repositories. Final disposal is permitted after specific treatment of immobilization processes by incorporating radioactive wastes in a borosilicate glass matrix, this process is also known as vitrification [3].

Vitrification is the most widely selected process for conditioning and immobilizing High Level Radioactive Waste (HLW) before final disposal in the geological formation repository. In comparison with other materials, glass has been preferred and most recommended material for immobilization. Vitrification is often chosen as the best technology for the immobilization of HLW because the resulted glass has good stability against many of the corrosive factors; however, for long run periods, strong extrinsic parameters (i.e. temperature, chemicals and solvents) are not safe for glass durability [4].

Corrosion of the nuclear borosilicate glass matrix in anaerobic conditions deep in the geological repository is highly predicted due to delay formation of the amorphous protective layer (gel) on the glass interface. 
Studying the durability of the high-level radioactive glass needs all possible methods, they are important to demonstrate all concerned alteration matters of the borosilicate glass matrix. Many researches have demonstrated that iron minerals (oxides and carbonates) are readily found in the deep geological formations where nuclear waste repositories are being constructed and they considered their effect on nuclear waste glass as significant [5-10]. Previous studies predicted influence of ankerite on durability of glass used for disposal of high level nuclear waste [8, 11, 12]. France (Callovo-Oxfordian Clayrock at Bure), Belgium (Boom Clay at Mol), Hungary (Boda Claystone at Mecsek), Switzerland (Opalinus Clay at Mont Terri and Benken, and Palfris Formation at Wellenberg), United Kingdom (Oxford Clay), and Canada (Queenston Formation) are the anticipated countries and geological formations for the high and medium-level radioactive waste final disposal repositories [13-15]. Table 1 shows the mineralogical composition of the Callovo-Oxfordian host-rock range by weight, as measured by AREVA at La Hage.

Si saturation is a mandatory condition to start formation of the protective gel layer, which is expected to minimize the contact surface between the glass and the aqueous surrounding; unless the external near-field corrosive factors (i.e. iron minerals) interrupt either the structure or the actual accumulation of this layer via keeping the medium far from Si saturation level in the long term $[4,5,16,17]$.

In this study the role of anhydrous carbonate minerals in reducing silicate concentration by sorption and precipitation are investigated and scheduled to be experimented by using a silica gel solution and one of the naturally occurring iron carbonate minerals, which consists mostly of ankerite.

Table 1 The mineralogical composition of the Callovo-Oxfordian hostrock range, by mass $[9,14]$

\begin{tabular}{lc}
\hline Mineral & Composition, mass\% \\
\hline Mica+illite & $11-17$ \\
Interstratified illite-smectite & $27-31$ (30-60 wt.\% smectite) \\
Chlorite & 2.0 \\
Kaolinite & $1.5-2.6$ \\
Plagioclase feldspars & 1.0 \\
Potassic feldspars & 1.9 \\
Quartz & $22-25$ \\
Calcite & $20-21$ \\
Dolomite/ Ankerite & 3.0 \\
Anatase/rutile & 0.3 \\
Pyrite & $0.7-0.8$ \\
Goethite/siderite & $1.6-1.9$ \\
\hline
\end{tabular}

\section{Experimental materials}

\subsection{Ankerite}

Ankerite - the ubiquitous iron carbonate mineral in soil is widely present in many clayey matrices and its dissolution leads to goethite $\mathrm{FeOOH}$ formation [13]. Previously; siderite has proved to be ankerite in the carbonatites, $\mathrm{Ca}(\mathrm{Fe}, \mathrm{Mg}, \mathrm{Mn})\left(\mathrm{CO}_{3}\right)_{2}$ [14]. Ankerite $\left(\mathrm{CaFe}\left(\mathrm{CO}_{3}\right)_{2}\right)$ has the same crystal structure as dolomite $\left(\mathrm{CaMg}\left(\mathrm{CO}_{3}\right)_{2}\right)[15]$ and is considered as a member of the dolomite group of minerals as it shares many similarities with siderite [16].

Siderite, ankerite and dolomite have shown significant identified precipitation in sandstone, when the $\mathrm{Fe}$ (II) source provider existed $[15,18]$. A mineralogical alteration and characterization study was performed in Japan regarding the interaction of bentonite/iron in a synthetic seawater medium at $80{ }^{\circ} \mathrm{C}$ for a period of four years. Ankerite and siderite were identified as the iron corrosion products of iron alterations [6].

In this study ankerite-rich geological samples are used, they were collected at mining area in Rudabánya, Hungary. The collected geological samples - after a preliminary examination - were crushed and ground, and this way samples of average composition were used in the experiment. ICP-OES and X-Ray Fluorescence (XRF) characterizations were done on the samples. The element composition of ankerite is illustrated in Table 2, other elements were found to be lower than the detection limit. The carbon (C) content is of difficult to be measured by either ICP-OES or XRF technics. To determine the $\mathrm{C}$ content we followed a technic written by Heiri et al. [19]. The measurement was made on average powder sample, and the result of $\mathrm{C}$ content measurement is $9.73 \mathrm{~m} \%$.

\subsection{Silica gel}

This work is a representative study that illustrates the potential impact of geological deposition conditions on the durability of the glass used for radioactive waste disposal. This glass could be influenced by iron mineral compositions or other parameters expected to delay the creation of the protective gel layer in unsaturated silica solutions. It is worth here mentioning that the silica gel is a well-known protective material which is used commonly against corrosion factors [20]. The nuclear waste packages in geological repositories could be in direct contact or even flooded by groundwater, which is responsible for glass dissolution [21]. Leakage of groundwater inside the concrete buffer surrounding the nuclear waste packages occurs through water diffusion per capillary absorption; this same mechanism 
Table 2 Elemental composition of ankerite by using ICP-OES and XRF techniques

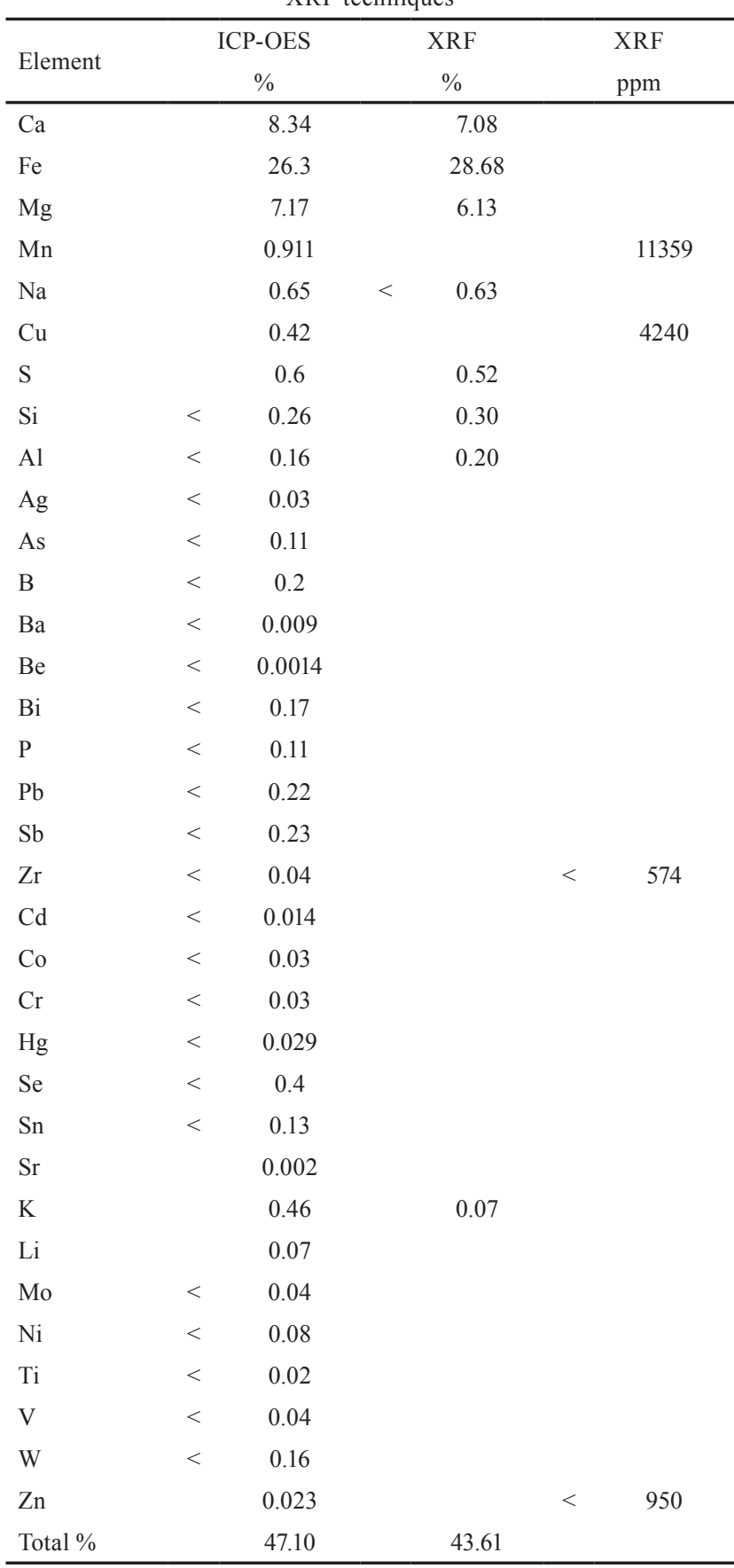

also influences the diffusion of water through varying rock densities, surface tension and contact angle values [22]. The porosity of the limestone, rhyolite tuff and density of stones are additional factors, which should be investigated to predict water absorption levels [23]. Studies regarding water motional mechanics inside the nuclear waste repository are paramount to estimate the level of groundwater saturation among the geological formation. Water can prompt borosilicate glass to convert into its main components by lowering its thermodynamic stability [24].
Philippini et al. stated that the interaction between glass and water at $90{ }^{\circ} \mathrm{C}$, the temperature of the nuclear waste at final disposal, is considered a potential risk on the durability of glass due to the higher rate of elemental removal through leaching [8].

In water saturated surroundings the dissolution of glass is a result of various processes:

1. the hydration of glass takes place by the diffusion of water into the glass network followed by ion exchange between positive protons that already exist in the groundwater and alkali metals in the glass formation, this leads to the hydration of glass and formation of an amorphous alteration layer (gel) on the glass surface due to the loss in mass of glass in the silica saturated environment;

2. the hydrolysis of the ionic-covalent bonds of the most soluble elements by attacking the glass network ( $\mathrm{Si}-\mathrm{O}-\mathrm{X} ; \mathrm{X}$ : Si, Al, Fe, Zr) bonds by groundwater;

3. the condensation mechanism where silica reversely reacts and is dissolved in groundwater then condensates as a gel layer influenced by both $\mathrm{pH}$ and temperature [7-9, 25].

In the current experimental work, high-purity, 15-25 $\mu \mathrm{m}$ silica gel, purchased from Merck was used to prepare diluted standard solutions.

\section{Sample preparation}

The ankerite stones were crushed into powder with tungsten carbide Electrical Mortar Grinder, and then they were sieved with Vibratory Sieve Shaker. The portion having grain size less than $45 \mu \mathrm{m}$ was collected.

Specific Surface Area (SSA) $0.12 \mathrm{~m}^{2} / \mathrm{g}$ was measured via Brunauer-Emmett-Teller BET-N ${ }_{2}$ method. Analysis using Particle Size Analyzer showed that $90 \%$ of the grains had a particle size below $39.16 \mu \mathrm{m}$ with a mean grains diameter of $16.63 \mu \mathrm{m}$. After milling, the powdered rock was dried overnight at $100{ }^{\circ} \mathrm{C}$ beyond being characterized using a D2 PHASER, Bruker AXS - X-Ray Diffraction and Elemental Analysis (XRD), the sample was found to be natural ankerite with slight quantities of dolomite.

Table 3 Surface characterization of $<45 \mu \mathrm{m}$ powdered ankerite,

\begin{tabular}{lcc}
\multicolumn{3}{c}{$\mathrm{SSA}=0.12 \mathrm{~m}^{2} / \mathrm{g}$} \\
\hline Sample ID & $\begin{array}{c}\text { Ankerite powder } \\
\text { Weight } \\
(\mathrm{g})\end{array}$ & $\begin{array}{c}\text { Surface area to Volume } \\
\text { ratio S/V } \\
\left(\mathrm{m}^{-1}\right)\end{array}$ \\
\hline M1 & 0.04 & 480 \\
M2 & 0.10 & 1200 \\
M3 & 0.30 & 3600 \\
\hline
\end{tabular}


Calculated Surface areas to Volume ratio (S/V) for samples are reported in Table 3.

Preparation of silicate saturated stock solution was carried out by adding $5 \mathrm{~g}$ silica gel to 1 liter of $0.01 \mathrm{~mol} / \mathrm{L}$ $\mathrm{NaOH}$ solution. The solution was mixed over 4 days in a polycarbonate container, then it was decanted; the clear solution part was filtered through Millipore filter pore size $0.45 \mu \mathrm{m}$. Silicon content in the solution was determined by ICP-OES using a silicon standard solution of $1 \mathrm{~g} / \mathrm{L}$ (1.12310.0500, Certipur, Merck KGaA). The $\mathrm{pH}$ of the filtered solution was set to 7 using diluted $\mathrm{HCl}$.

Silicon content of the $\mathrm{Na}_{2} \mathrm{SiO}_{4}$ standard solution is: $224 \mathrm{mg} / \mathrm{L} \mathrm{Si}(7.98 \mathrm{mmol} / \mathrm{L})$. All ICP-OES measurements were carried out beyond dilution/ digestion by $2 \mathrm{ml}$ $\mathrm{HNO}_{3}(63 \%)+2 \mathrm{ml} \mathrm{HCl}(37 \%)$.

\section{Methodology}

Table 4 shows all the experimental conditions used. A Varian AA6 AAS instrument and Perkin Elmer HGA500 graphite furnace GF-AAS instrument were chosen for the primary measurement of silicate sorption by ankerite from the standard silicate solution, S/V calculations in Table 3 were done on $10 \mathrm{ml}$ volume of silicate standard solution in each reactor vessel.

Depending on the spectral line used; GF-AAS can measure $\mathrm{Si}$ concentrations in relatively low ranges of either $0.1-2.4 \mathrm{ppm}$ or $0.2-6.0 \mathrm{ppm}$. Only $1 \mathrm{~mL}$ of solution is required and the detection limit was low enough for the accurate measurement of the samples.

\begin{tabular}{lc}
\multicolumn{2}{c}{ Table 4 Experimental conditions } \\
\hline Temperature & Room temperature \\
\hline Pressure & 1 atm \\
Atmosphere & Room atmosphere \\
$\mathrm{pH}$ & 7.0 \\
Reactor vessels & Polycarbonate \\
Si concentration $[\mathrm{Si}]$ & 3.6 ppm \\
Dilution & Distilled water \\
Si saturation & Under solubility limit \\
\hline
\end{tabular}

Table 5 Temperature profile for Si calibration curve used in GF-AAS

\begin{tabular}{lccccc}
\hline Step & 1 & 2 & 3 & 4 & 5 \\
Temperature $\left({ }^{\circ} \mathrm{C}\right)$ & 150 & 600 & 20 & 2,600 & 2,600 \\
Ramp time (s) & 1 & 1 & 1 & 0 & 0 \\
Hold time (s) & 15 & 5 & 15 & 3 & 1 \\
Read & & & 11 & & \\
Flow (ml/min) & & & & 30 & \\
\hline
\end{tabular}

Table 6 Concentration of silicate standard solutions prepared for GF-

\begin{tabular}{lcc}
\multicolumn{3}{c}{ AAS calibration } \\
\hline $\mathrm{Si}$ & Stock $224 \mathrm{ppm} \mathrm{Si}$ & $0.01 \mathrm{~mol} / \mathrm{L} \mathrm{NaNO3}$ \\
\hline $\mathrm{ng} / \mathrm{ml}$ & $\mathrm{ml}$ & $\mathrm{ml}$ \\
450 & 0.05 & 25 \\
1,200 & 0.13 & 25 \\
2,400 & 0.27 & 25 \\
3,600 & 0.40 & 25 \\
\hline
\end{tabular}

\subsection{Silicon calibration curve}

A sub-sample of $20 \mu \mathrm{L}$ of the matrix solution $0.01 \mathrm{~mol} / \mathrm{L}$ $\mathrm{NaNO}_{3}$ was manually injected and processed as the temperature profile illustrated in Table 5 .

Standard solutions were prepared for Si calibration process (Table 6). They were prepared by diluted fraction from silicate stock solution of $224 \mathrm{ppm}(7.98 \mathrm{mmol} / \mathrm{L})$ silicon concentration and $0.01 \mathrm{~mol} / \mathrm{L} \mathrm{NaNO}_{3}$ added. The standard solutions were used as background solution.

Fig. 1 shows a calibration curve, which was built using diluted solutions of different $\mathrm{Si}$ concentrations from the stock solution. Very low concentrations of Si were able to be analyzed via the GF-AAS.

\subsection{Sorption of Si on ankerite powder}

Sorption study of $\mathrm{H}_{4} \mathrm{SiO}_{4}$ from $3.6 \mathrm{ppm} \mathrm{Si}(0.128 \mathrm{mmol} / \mathrm{L})$ solution was performed in parallel on three dual weights of ankerite: M1 $0.04 \mathrm{~g}, \mathrm{M} 20.1 \mathrm{~g}$ and M3 $0.3 \mathrm{~g}$.

Weighted ankerite powders were poured into $15 \mathrm{ml}$ centrifuge tubes. Then, $10 \mathrm{ml}$ of $\mathrm{Si}$ test solution $\left(\mathrm{H}_{4} \mathrm{SiO}_{4}\right)$ with $3.6 \mathrm{ppm} \mathrm{Si}$ in $0.01 \mathrm{~mol} / \mathrm{L} \mathrm{NaNO}_{3}$ was added into all tubes. The tubes were closed and then placed into rotary mixer and mixed for $12 \mathrm{~h}$ at rpm 30 .

The tubes were then centrifuged during $10 \mathrm{~min}$ for solid/liquid separation. The solution was carefully poured

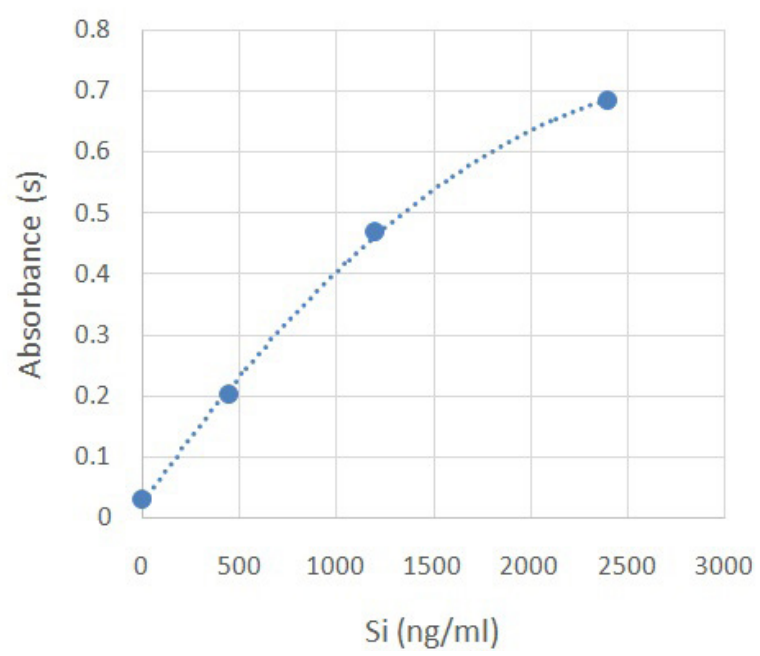

Fig. 1 GF-AAS silicon calibration curve 
Table 7 Silicon adsorption on ankerite powder

\begin{tabular}{|c|c|c|c|c|c|c|}
\hline \multirow{3}{*}{ ID } & Mass & $\mathrm{m} / \mathrm{v}$ & Initial & Final & Adsorbed & Adsorbed \\
\hline & \multirow{2}{*}{ (g) } & \multirow{2}{*}{$(\mathrm{g} / 1)$} & {$[\mathrm{Si}]$} & {$[\mathrm{Si}]$} & [Si] & [Si] \\
\hline & & & $(\mu \mathrm{g})$ & $(\mu \mathrm{g})$ & $(\mu \mathrm{g})$ & $(\%)$ \\
\hline \multirow{2}{*}{ M1 } & 0.04 & 4 & 4.84 & 36 & 31.2 & 86.6 \\
\hline & 0.04 & 4 & 5.4 & 36 & 30.6 & 85.0 \\
\hline \multirow{2}{*}{ M2 } & 0.1 & 10 & 1.74 & 36 & 34.3 & 95.2 \\
\hline & 0.1 & 10 & 1.14 & 36 & 34.9 & 96.8 \\
\hline \multirow{2}{*}{ M3 } & 0.3 & 30 & 0.5 & 36 & 35.5 & 98.6 \\
\hline & 0.3 & 30 & 0.33 & 36 & 35.7 & 99.1 \\
\hline
\end{tabular}

into a $25 \mathrm{ml}$ HDPE container. About $2 \mathrm{ml}$ of the solution was sucked into a $5 \mathrm{ml}$ syringe and filtered through Millipore syringe filter pore size $0.45 \mu \mathrm{m}$ into a $5 \mathrm{ml}$ HDPE container. Concentrations of all solutions were measured by the GF-AAS instrument. Characterization results are summarized in Table 7.

\subsection{Desorption of silicon from the ankerite powder}

Desorption of $\mathrm{H}_{4} \mathrm{SiO}_{4}$ from the solid material after its initial adsorption was also detected through the current study. $10 \mathrm{ml}$ of $0.01 \mathrm{~mol} / \mathrm{L} \mathrm{NaNO}_{3}$ was added to the centrifuge tubes containing the ankerite remaining from adsorption. The tubes were closed and placed on a rotary mixer; they were left to be mixed for 12 hours at $30 \mathrm{rpm}$.

Desorption study over this work was in similar process way used for separation of solid/liquid, as it has been done in the sorption part (Subsection 4.2): the tubes were then centrifuged during $10 \mathrm{~min}$ for solid/liquid separation. The solution was carefully poured into a $25 \mathrm{ml}$ HDPE container. About $2 \mathrm{ml}$ of the solution was sucked into a $5 \mathrm{ml}$ syringe and filtered through Millipore syringe filter pore size $0.45 \mu \mathrm{m}$ into a $5 \mathrm{ml}$ HDPE container. Concentrations of all solutions were measured by the GF-AAS instrument. Results of desorption process are summarized in Table 8.

\section{Data analysis and discussion}

Table 8 Desorption of silicon from ankerite back to the solution

\begin{tabular}{|c|c|c|c|c|c|}
\hline \multirow{3}{*}{ ID } & Mass & $\mathrm{m} / \mathrm{v}$ & Adsorbed & Desorbed & Desorbed \\
\hline & \multirow{2}{*}{ (g) } & \multirow{2}{*}{$(\mathrm{g} / 1)$} & {$[\mathrm{Si}]$} & {$[\mathrm{Si}]$} & {$[\mathrm{Si}]$} \\
\hline & & & $(\mu \mathrm{g})$ & $(\mu \mathrm{g})$ & $(\%)$ \\
\hline \multirow{2}{*}{ M1 } & 0.04 & 4 & 31.2 & 2.84 & 9.1 \\
\hline & 0.04 & 4 & 30.6 & 2.65 & 8.7 \\
\hline \multirow{2}{*}{ M2 } & 0.1 & 10 & 34.3 & 1.69 & 4.9 \\
\hline & 0.1 & 10 & 34.9 & 1.2 & 3.4 \\
\hline \multirow{2}{*}{ M3 } & 0.3 & 30 & 35.5 & 0.84 & 2.4 \\
\hline & 0.3 & 30 & 36.7 & 1.78 & 4.9 \\
\hline
\end{tabular}

Validation of the actual consequences of geological impact on high-level radioactive packages by simulation method studies is a tedious task, gathering all output results is important for better understanding of glass corrosion consequences but considered as approximations due to the time limitation constraints. Studies tracking the alterations on nuclear glass carried out for days, months or even years are unable to give exact knowledge of what will actually happen to the glass after hundreds of thousands of years, but such studies are able to result in reassured predictions.

In real conditions nuclear waste disposal glass alteration will stop month later to the leaching, and silicate saturation level is reached unless disturbance parameters come out with significant effecting factors delay achievement of silicate saturation status.

The role of Si sorption on the surfaces of the solid near field clay rock is considered as one factor or even the most effective one.

Ankerite, the Fe-bearing mineral ferrous compound, is highly predicted to carry out that through couple effecting factors promote delay Si saturation:

1. $\mathrm{Fe} / \mathrm{Si}$ precipitations due to relatively high $\mathrm{Fe}$ flux in the solution,

2. role of Si sorption on its surfaces.

The current study focused on Si sorption factor and results show strong adsorption capacity of Si by ankerite. 86-99\% of Si molecules were absorbed from the solution Fig. 2.

Desorption results were slightly higher for lower $\mathrm{m} / \mathrm{v}$ ratios but showed generally weak power of ankerite in releasing the adsorbed Si molecules back into solution, Fig. 3. That can be explained either by the fact that mixing time was insufficient or "chemisorption" type occurred.

Delaying Si saturation is attributed to many reasons, iron minerals activities in the aqueous medium were

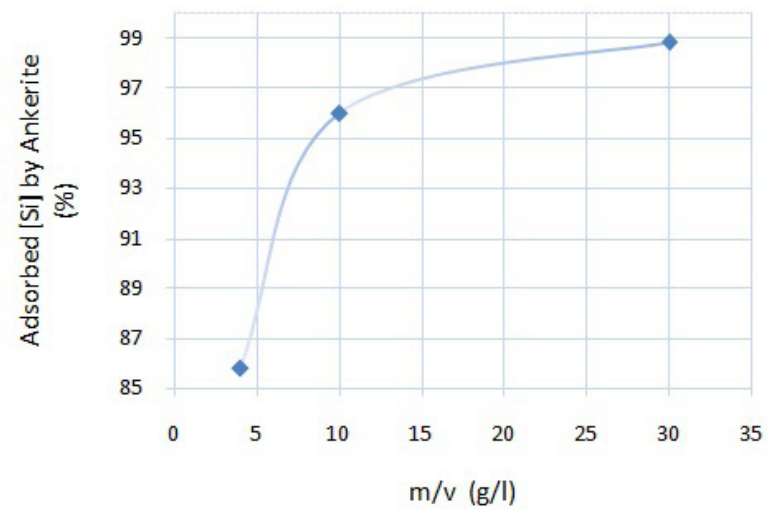

Fig. 2 Silicon adsorption on different ankerite masse to volume ratios after leaching for 12 hours 


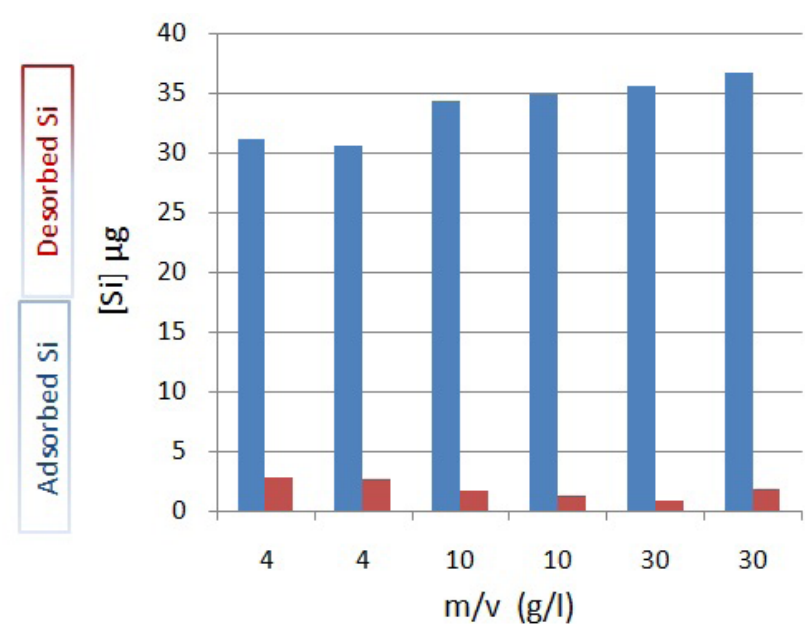

Fig. 3 Adsorption and desorption values of $\mathrm{Si}$

diagnosed highly positive in this regards. They promote highly the reduction of the silicate saturation level in the silicate solution. This study is part of investigation framework focusing on ankerite capacity in uptaking silicates from surrounding medium.

$\mathrm{Fe} / \mathrm{Si}$ and $\mathrm{Mg} / \mathrm{Si}$ have been confirmed in other researches significant delaying factors for $\mathrm{Si}$ saturation, and they showed active role in preventing formation of the amorphous protective layer (gel) $[9,10]$. Table 2 clarifies that concentrations of both $\mathrm{Fe}$ and $\mathrm{Mg}$ in ankerite are sufficient to do so; therefore, authors would recommend more investigations on ankerite in terms of $\mathrm{Fe} / \mathrm{Si}$ and $\mathrm{Mg} / \mathrm{Si}$ precipitations. Ankerite is candidate among this study an iron carbonate mineral compound accelerates the alteration of nuclear glass in the real repository over long time storage through its confirmed $\mathrm{Si}$ adsorption capability; however precipitations of $\mathrm{Si}$ compounds perhaps promote that as well.

Previous researches $[8,26]$ used a synthetic silica solution to study the sorption capacity of Si on different iron corrosion products or iron mineral compounds i.e. iron carbonates: siderite, $\mathrm{FeCO}_{3}$; dolomite, $\mathrm{CaMg}\left(\mathrm{CO}_{3}\right)_{2}$; and iron oxides: magnetite, $\mathrm{Fe}_{3} \mathrm{O}_{4}$; goethite, $\alpha-\mathrm{FeOOH}$. These studies have already confirmed the occurrence of sorption over different levels.

Jordan et al. [26] and Philippini et al. [8] confirmed silicates sorption on goethite. During the first $24 \mathrm{~h}$ of cultivation, Si sorption capacity of goethite was estimated quadruple more than that of magnetite and siderite, which perhaps corresponds to what was found for ankerite in this study. They both confirmed optimum $\mathrm{pH}$ for $\mathrm{Si}$ sorption at 8.5 which was not far from the $\mathrm{pH}$ used for ankerite. However, ankerite showed weak converse desorption behavior of Si.
Philippini et al. [8] recommended including ankerite in such Si sorption studies as well as higher temperature levels. More research studies on ankerite are under performance among the current $\mathrm{PhD}$ study on alterations of International Simple Glass ISG (inactive analogue of the French R7T7 HLW glass) in presence of ankerite in different reacting temperatures up to $90{ }^{\circ} \mathrm{C}$ attempting to confirm by evidence whether ankerite has a positive role in accelerating alterations of the nuclear waste glass in the actual repository site or not.

\section{Conclusion}

In this paper, authors studied the role of ankerite in reducing the saturation levels of silicate in solution; this helps to explain the important geological factor of accelerating nuclear glass alteration in the final disposal repository. GF-AAS analysis was used for measurements of silicon concentrations. The current study shows evidence that higher ankerite surface area conduces to higher capacity of adsorption. Experimental observations reveal that ankerite has strong ability to decrease the concentration of dissolved silica in the standard solution via adsorption; conversely, they reveal weak desorption abilities explained either by the fact that mixing time was insufficient or "chemisorption" type occurred.

Further experiments should be performed on several of different silicon concentrations over longer time durations and wider range of $\mathrm{pH}$ to obtain better understanding of the optimum conditions for silicon sorption by ankerite and to study the desorption mechanism much more conveniently. Both sorption and desorption mechanisms are important parameters for reaching equilibrium.

\section{Acknowledgement}

The Stipendium Hungaricum Scholarship Programme is highly acknowledged for supporting $\mathrm{PhD}$ studies and research. The authors acknowledge the support and help of Professor László Bezur from the Department of Inorganic and Analytical Chemistry, Budapest University of Technology and Economics for GF-AAS and ICPOES characterization and silicate solution preparation. The authors would also like to acknowledge the support of Eng. Ahmad Abukashabeh, Eng. Rachael Abu-Halimeh, Mrs. Ala'a Maani and Mr. Ahmad Almansi from Jordan Atomic Energy Commission for XRD, XRF, BET-N ${ }_{2}$, and PSA measurements. 


\section{References}

[1] Pátzay, G., Weiser, L., Feil, F., Schunk, J., Patek, G. "Radioactive wastewater treatment using selective ion exchangers", Periodica Polytechnica Chemical Engineering, 53(2), pp. 67-69, 2009. https://doi.org/10.3311/pp.ch.2009-2.06

[2] Chon, J. K., Beaudoin, V., Pitcher, C. S. "Conceptual design of volume reduction system for ITER low level radioactive waste, Fusion Engineering and Design, 109-111, pp. 1001-1004, 2016. https://doi.org/10.1016/j.fusengdes.2016.01.035

[3] Druyts, F., Van Iseghem, P. "Conditioning methods for beryllium waste from fusion reactors", Fusion Engineering and Design, 69(1-4), pp. 607-610, 2003.

https://doi.org/10.1016/s0920-3796(03)00169-8

[4] Rebiscoul, D., Frugier, P., Gin, S., Ayral, A. "Protective properties and dissolution ability of the gel formed during nuclear glass alteration", Journal of Nuclear Materials, 342(1-3), pp. 26-34, 2005. https://doi.org/10.1016/j.jnucmat.2005.03.018

[5] Inagaki, Y., Kikunaga, T., Idemitsu, K., Arima, T. "Initial Dissolution Rate of the International Simple Glass as a Function of $\mathrm{pH}$ and Temperature Measured Using Microchannel FlowThrough Test Method", International Journal of Applied Glass Science, 4(4), pp. 317-327, 2013.

https://doi.org/10.1111/ijag.12043

[6] Wersin, P., Snellman, M. "Impact of iron on the performance of clay barriers in waste disposal systems: Report on the status of research and development", Svensk Kärnbränslehantering AB, Swedish Nuclear Fuel and Waste Management Co., Stockholm, Sweden, Rep. R-08-45, 2008.

[7] Gin, S. "Open Scientific Questions about Nuclear Glass Corrosion", Procedia Materials Science, 7, pp. 163-171, 2014.

https://doi.org/10.1016/j.mspro.2014.10.022

[8] Philippini, V., Naveau, A., Catalette, H., Leclercq, S. "Sorption of silicon on magnetite and other corrosion products of iron", Journal of Nuclear Materials, 348(1-2), pp. 60-69, 2006.

https://doi.org/10.1016/j.jnucmat.2005.09.002

[9] Burger, E., Rebiscoul, D., Bruguier, F., Jublot, M., Lartigue, J. E., Gin, S. "Impact of iron on nuclear glass alteration in geological repository conditions: A multiscale approach", Applied Geochemistry, 31, pp. 159-170, 2013. https://doi.org/10.1016/j.apgeochem.2012.12.016

[10] Debure, M., Frugier, P., De Windt, L., Gin, S. "Dolomite effect on borosilicate glass alteration", Applied Geochemistry, 33, pp. 237-251, 2013.

https://doi.org/10.1016/j.apgeochem.2013.02.019

[11] Al Dabbas, A., Kopecskó, K. "Corrosion of glass used for radioactive waste disposal - state of the art", Pollack Periodica, 14(1), pp. 85-94, 2019. https://doi.org/10.1556/606.2019.14.1.9

[12] Al Dabbas, A., Kopecskó, K. "Corrosion of glass used for radioactive waste disposal influenced by iron corrosion products", IOP Conference Series: Materials Science and Engineering, 613, Article Number: 012030, 2019. https://doi.org/10.1088/1757-899x/613/1/012030
[13] Breitner, D., Osán, J., Fábián, M., Zagyvai, P., Szabó, C., Dähn, R., Marques Fernandes, M., Sajó, I. E., Máthé, Z., Török, S. "Characteristics of uranium uptake of Boda Claystone Formation as the candidate host rock of high level radioactive waste repository in Hungary", Environmental Earth Sciences, 73(1), pp. 209-219, 2015. https://doi.org/10.1007/s12665-014-3413-4

[14] Gaucher, E. C., Tournassat, C., Pearson, F. J., Blanc, P., Crouzet, C., Lerouge, C., Altmann, S. "A robust model for pore-water chemistry of clayrock", Geochimica et Cosmochimica Acta, 73(21), pp. 6470-6487, 2009. https://doi.org/10.1016/j.gca.2009.07.021

[15] Buocz, I., Rozgonyi-Boissinot, N., Török, Á., Görög, P. "Direct shear strength test on rocks along discontinuities, under laboratory conditions", Pollack Periodica, 9(3), pp. 139-150, 2014. https://doi.org/10.1556/pollack.9.2014.3.15

[16] Vernaz, E., Gin, S., Jégou, C., Ribet, I. "Present understanding of R7T7 glass alteration kinetics and their impact on long-term behavior modeling", Journal Nuclear Materials, 298(1-2), pp. 27-36, 2001. https://doi.org/10.1016/S0022-3115(01)00643-2

[17] Gin, S., Ribet, I., Couillard, M. "Role and properties of the gel formed during nuclear glass alteration: importance of gel formation condition", Journal of Nuclear Materials, 298(1-2), 2001, pp. 1-10. https://doi.org/10.1016/s0022-3115(01)00573-6

[18] Xu, T., Apps, J. A., Pruess, K. "Mineral sequestration of carbon dioxide in a sandstone-shale system", Chemical Geology, 217(3-4), pp. 295-318, 2005. https://doi.org/10.1016/j.chemgeo.2004.12.015

[19] Heiri, O., Lotter, A. F., Lemcke, G. "Loss on ignition as a method for estimating organic and carbonate content in sediments: reproducibility and comparability of results", Journal of Paleolimnology, 25(1), pp. 101-110, 2001. https://doi.org/10.1023/A:1008119611481

[20] Volentiru, E., Nyári, M., Szabó, G., Hórvölgyi, Z., Mureşan, L. M. "Silica sol - gel protective coatings against corrosion of zinc substrates", Periodica Polytechnica Chemical Engineering, 58(Supplement), pp. 61-66, 2014. https://oi.org/10.3311/PPch.7302

[21] Jollivet, P., Frugier, P., Parisot, G., Mestre, J. P., Brackx, E., Gin, S., Schumacher, S. "Effect of clayey groundwater on the dissolution rate of the simulated nuclear waste glass SON68", Journal of Nuclear Materials, 420(1-3), pp. 508-518, 2012. https://doi.org/10.1016/j.jnucmat.2011.10.026

[22] Juhász, P., Kopecskó, K., Suhajda, Á. "Analysis of capillary absorption properties of porous limestone material and its relation to the migration depth of bacteria in the absorbed biomineralizing compound", Periodica Polytechnica Civil Engineering, 58(2), pp. 113-120, 2014. https://doi.org/10.3311/PPci.7020

[23] Farkas, O., Török, Á. "Effect of Exhaust Gas on Natural Stone Tablets, a Laboratory Experiment", Periodica Polytechnica Civil Engineering, 63(1), pp. 115-120, 2019. https://doi.org/10.3311/PPci.12708 
[24] Paul, A. "Chemical durability of glasses; a thermodynamic approach", Journal of Materials Science, 12(11), pp. 2246-2268, 1977.

https://doi.org/10.1007/BF00552247

[25] Bouakkaz, R., Abdelouas, A., El Mendili, Y., Grambow, B., Gin, S. "SON68 glass alteration under Si-rich solutions at low temperature $\left(35-90^{\circ} \mathrm{C}\right)$ : kinetics, secondary phases and isotopic exchange studies", RSC Advances, 6(76), pp. 72616-72633, 2016.

https://oi.org/10.1039/C6RA12404F
[26] Jordan, N., Marmier, N., Lomenech, C., Giffaut, E., Ehrhardt, J. J. "Sorption of silicates on goethite, hematite, and magnetite: Experiments and modeling", Journal of Colloid and Interface Science, 312(2), pp. 224-229, 2007.

https://doi.org/10.1016/j.jcis.2007.03.053 